\title{
ENXADA, CANETA E MOUSE: O DIÁLOGO ENTRE TECNOLOGIAS NA FORMAÇÃO CONTINUADA DE PROFESSORES DO CAMPO NA MODALIDADE A DISTÂNCIA
}

\author{
MIRAÍRA NOAL MANFROI ${ }^{1}$ \\ ORCID: https://orcid.org/0000-0003-0135-0697
}

MIRIAN LANGE NOAL ${ }^{2}$

ORCID: https://orcid.org/0000-0002-3578-8032

\begin{abstract}
RESUMO: A educação do campo é um direito cidadão, assim como a inclusão digital. A concepção teórica escolhida compreende que há diferentes saberes, diversas tecnologias e múltiplas possibilidades de colocá-las como parceiras nos processos de ensino e de aprendizagem. A pesquisa contou com a participação de quinze tutores e dois coordenadores do Curso de Especialização em Educação do Campo/UFMS/EaD. Também participou uma liderança do campo, professor e concluinte da primeira edição do Curso. A pesquisa enfatizou que as tecnologias eletrônico-digitais estão presentes no cotidiano do campo de MS, mas com diferentes níveis de qualidade ao acesso e aos equipamentos, sendo o aspecto mais comprometedor a internet. Mesmo assim, essas tecnologias se constituem como caminhos para a formação continuada, com o cuidado de não negarem os saberes do campo e não se contraporem ao tempo cíclico do plantio, da oralidade, da terra como espaço e expressão da vida em comunidade.
\end{abstract}

Palavras-chave: Educação do campo; Inclusão digital; Formação continuada; Ensino a distância.

\section{HOE, PEN AND MOUSE: THE DIALOGUE BETWEEN TECHNOLOGIES IN CONTINUING EDUCATION OF FIELD TEACHERS IN DISTANCE MODE}

\footnotetext{
ABSTRACT: Field education is a citizen's right, as the digital inclusion. The theoretic conception chosen comprehends that there are different knowledges, different technologies and multiple possibilities to place them as partners in teaching and learning processes. Fifteen tutors and two coordinators in the Field Education Specialization Course / UFMS / EAD participated in the research.Also participated a field leadership, teacher and the first edition of the Course concluding .The research emphasized that electronic-digital technologies are present in the daily life of the MS field, but with different levels of quality acesso and equipment, being the most compromising aspect the internet. Even so, these technologies constitute paths for continuing education, with the care not to deny the field knowledge

${ }^{1}$ Universidade Federal de Santa Catarina. Florianópolis $|\mathrm{SC}|$ Brasil<mira_nm@hotmail.com>

${ }^{2}$ Universidade Federal do Mato Grosso do Sul. Campo Grande |MS |Brasil

$<$ miriannoal@gmail.com>
} 
and not to oppose the planting cyclic time,the orality, or land as a space and expression of community life.

Keywords: Field education; Digital inclusion; Continuing education; Distance learning.

\title{
AZADA, BOLÍGRAFO Y RATÓN: EL DIÁLOGO ENTRE TECNOLOGÍAS EN LA FORMACIÓN CONTINUA DE PROFESORES DEL CAMPO EN LA MODALIDAD A DISTANCIA
}

RESUMEN: La educación del campo es un derecho de los ciudadanos, como lo es la inclusión digital. La concepción teórica elegida comprende que existen diferentes conocimientos, diversas tecnologías y múltiples posibilidades de colocarlos como colaboradores en los procesos de enseñanza y de aprendizaje. Participaron de la investigación quince tutores y dos coordinadores del Curso de Especialización en Educación del Campo /UFMS/EaD. También participó un líder del campo, profesor y concluyente de la primera edición del Curso. La investigación enfatizó que las tecnologías electrónicas y digitales están presentes en la vida diaria del campo de MS, pero con diferentes niveles de calidad alacceso y a los equipamientos, siendo la internet el aspecto más comprometido. Aun así, esas tecnologías constituyen posibilidades de formación continua, cuidando de no negar los saberes del campo y no se oponer al tiempo ć́clico de la plantación, de la oralidad, de la tierra como espacio y expresión de la vida en comunidad.

Palabras clave: Educación del campo; Inclusión digital; Formación continua; Educación a distancia.

\section{INTRODUÇÃO}

\begin{abstract}
Em primeiro lugar, faço questão enorme de ser um homem de meu tempo e não um homem exilado dele, o que vale dizer que não tenho nada contra as máquinas. De um lado, elas resultam e de outro estimulam o desenvolvimento da ciência e da tecnologia, que, por sua vez, são criações humanas. $O$ avanço da ciência e da tecnologia não é tarefa de demônios, mas sim a expressão da criatividade humana. Por isso mesmo, as recebo da melhor forma possivel. Para mim, a questão que se coloca é: a serviço de quem as máquinas e a tecnologia avançada estão? Quero saber a favor de quem, ou contra quem as máquinas estão postas em uso. [...] Para mim os computadores são um negócio extraordinário. O problema é saber a serviço de quem eles entram na escola. (Paulo Freire, 1984)
\end{abstract}

O campo, mais do que um perímetro não urbano, se constitui de tempos e de espaços que gestam possibilidades e que permeiam as relações sociais tendo a terra como elemento de vida (e de morte). Como qualquer outro lugar, o campo apresenta conflitos, limites e contradições, apesar de apresentar, historicamente e com foco no coletivo, projetos contextualizados e politizados de sociedade, de homem, de mulher, de plantio, de colheita, de distribuição dos frutos do trabalho.

Neste artigo, o foco é o campo das pequenas propriedades rurais, dos assentamentos e dos acampamentos localizados em Mato Grosso do Sul (MS). O campo das roças, da diversidade de plantio, do gado leiteiro, dos pequenos animais, dos mutirões, da agricultura familiar, das festas religiosas, das festas populares, da oralidade. Mas também o campo dos conflitos e das lutas sangrentas pela terra e pelo direito de nela permanecer e dela sobreviver. Campo que utiliza diferentes tecnologias, que vão desde as enxadas e demais ferramentas, até os computadores, a internet e os celulares digitais. 
Para que se compreendam os contextos do campo em MS, é importante destacar que estamos em um Estado com baixa densidade demográfica, com insipiente parque industrial, mas com grandes reservas naturais. O Pantanal, e as suas planícies de inundação contínua, têm 65\% de suas áreas em território sul-mato-grossense, que, também, se destaca pela região de Bonito com as suas serras, grutas, rios cristalinos e fauna diversificada. Essas reservas naturais têm expandido o ecoturismo, representando importante fonte econômica, mas acessível, de maneira geral, somente ao fluxo externo de turistas. Em MS, como no restante do Brasil, não tem sido facilitado o acesso das populações sul-mato-grossenses às belezas naturais, pois as políticas públicas locais estão sob o domínio de grupos que, historicamente, têm mantido privilégios e exceções e, não raro, disseminado a destruição ambiental. Atualmente, a expansão das culturas da cana-de-açúcar e do eucalipto precisam ser repensadas, pois a implantação e a ampliação das usinas de álcool e das indústrias de celulose impactam as populações do campo e geram destruição aos ecossistemas, abandono de pequenas propriedades, exclusões, disputas, violências e mortes.

Estudos, como os desenvolvidos por Capra (1975, 1982, 1996, 2002), Maturana e Varela (2001), evidenciam algumas consequências que esses processos destrutivos trazem, interferindo nas relações sociais, na dinâmica de convivência e na economia familiar, nos processos vitais em todas as suas manifestações. Estamos conectados uns com os outros e com os processos de produção e de intervenção na natureza, pois a vida é complexa, multidimensional e se faz por meio de relações, comunicações e ações.

Nesses contextos, brevemente apresentados, os grupos sociais excluídos, principalmente os que residem no campo em MS, ficam marginalizados dos processos decisórios que envolvem as políticas públicas, não sendo diferente com relação ao acesso às tecnologias, foco deste artigo. As perguntas que fomentaram o interesse em desenvolver a pesquisa foram: a) Como os alunos do Curso de Especialização em Educação do Campo, ofertado pela Universidade Federal de Mato Grosso do Sul (UFMS), na modalidade a distância, acessam os materiais disponibilizados no ambiente virtual de aprendizagem (Moodle)? Quais as principais dificuldades apresentadas por esses alunos com relação ao acesso e ao uso das tecnologias eletrônico-digitais ${ }^{3}$ ? Qual a opinião e o que sugerem os tutores, os coordenadores e uma liderança?

A pesquisa desenvolvida teve como objetivo geral compreender como os alunos do Curso de Especialização em Educação do Campo (Curso), ofertado pela UFMS, na modalidade a distância, acessam os materiais disponibilizados e como participam das práticas político-

\footnotetext{
${ }^{3}$ Neste artigo será utilizado o termo "tecnologias eletrônico-digitais" na tentativa de não reduzir os equipamentos e as experiências dos alunos do Curso, ampliando as possibilidades de inclusão de diferentes tecnologias, mas também na busca intencional de diferenciar as tecnologias manuais das eletrônicas.

Educação em Revista|Belo Horizonte|v.36|e215770|2020
} 
pedagógicas desenvolvidas via Moodle. Nessa proposta, os objetivos específicos foram: a) avaliar a qualidade e a quantidade dos equipamentos eletrônico-digitais que estão disponíveis aos alunos; b) conhecer as habilidades e as dificuldades apresentadas pelos alunos no uso do computador e da internet; c) analisar se há inclusão digital dos alunos do Curso que residem em regiões localizadas no campo em MS; d) colaborar com a problematização e a compreensão das possibilidades e dos limites da inclusão digital em relação às populações do campo de MS.

A concepção teórica que fundamentou a pesquisa parte do pressuposto de que as tecnologias são diversas e que há possibilidades diferentes de se tornarem parceiras nos processos de ensino e de aprendizagem. Os saberes e as tecnologias próprias do cotidiano campesino foram considerados no mesmo patamar dos saberes e das tecnologias eletrônicodigitais, sem considerar umas como atrasadas e outras como avançadas, sem que se evidenciasse a supremacia de uma tecnologia sobre a outra. Também se compreendeu que, "as experiências e os conhecimentos clássicos do campo" (NOAL, 2010) são vitais em determinados momentos, mas que não impedem o diálogo com as chamadas novas tecnologias.

O convite é para se desmistificar a palavra tecnologia e aproximá-la, historicamente, do cotidiano da vida do campo, no qual rádios, arados, panelas, telefones, livros, televisões, cadeiras, cartazes, carros, lâmpadas, lamparinas, carroças, computadores e tantas outras, dialogam e têm, cada uma, a sua especificidade. Historicamente - da pedra lascada, da roda e do fogo - a humanidade tem criado instrumentos e técnicas que têm assegurado a sobrevivência, que têm garantido melhores condições de vida e que facilitaram a relação da humanidade com a natureza (CHASSOT, 1997). Essas invenções, apresentadas no filme "A guerra do fogo", transformaram significativamente os processos de intervenção na natureza, revolucionando as relações humanas e as organizações sociais. No entanto, é essencial destacar que nenhuma tecnologia é neutra, pois há o seu atrelamento aos contextos sociais, políticos e econômicos, que, ao mesmo tempo que podem ser propulsores, podem ser impeditivos ou marcados ideologicamente pelo interesse de classes (OLIVEIRA; REGO; VILLARDI, 2007).

As tecnologias, como qualquer criação humana, trazem em seu bojo contradições e possibilidades, avanços e retrocessos, aprendizagens e desaprendizagens, memórias e esquecimentos. Dialeticamente são novidades, mas nascem de antigos conhecimentos

\footnotetext{
${ }^{4}$ O filme "A Guerra do Fogo" (Jean-Jacques Annaud; Anthony Burgess, 1981) percorre o período da pré-história para apresentar os processos de evolução dos homens primitivos, suas relações entre si e com a natureza, bem como as suas transformações em decorrência dessas relações: o desenvolvimento da linguagem, da capacidade de abstração e discernimento; o conhecimento por meio da transformação da natureza; as novas organizações sociais. O fogo, ainda misterioso e sobrenatural para alguns, é objeto de disputas. A cena inicial se repete ao final do filme, com uma fogueira ao longe. As duas cenas representam situações diferentes apesar da mesma paisagem. Na primeira, temos uma tribo que teme o desconhecido e necessita manter a chama acesa para sua própria sobrevivência. Na última, uma nova tribo que domina o fogo e está pronta para o desenvolvimento e continuidade das espécies. (OLIVEIRA; SANTOS, 2012).
} 
ressignificados. Dinamicamente possibilitam trocas, e estabelecem o diálogo entre diferentes conhecimentos, no exercício da "circularidade cultural” (GINZBURG, 1987).

Tomemos, por exemplo, um computador de última geração e nele teremos fragmentos das quase esquecidas máquinas de escrever. Assim como diante de um aparelho de ar condicionado moderno encontraremos o mesmo princípio de amenizar o calor dos antigos leques e dos primeiros ventiladores. E, nesse percurso, é importante evidenciar que em determinados momentos ainda utilizamos lápis e papel na ausência de um computador, assim como usamos o velho e charmoso leque. Assim, por opção, por crises de energia, catástrofes e outras situações de exceção, os grupos sociais retornam às tecnologias aparentemente obsoletas, tão antigas como a humanidade, sendo possível reconhecer a linha condutora das ligações que vão desde a arte rupestre até os sistemas de informações digitais, evidenciando a relevância de cada etapa e indicando a necessidade do diálogo entre o antigo e o novo, principalmente no campo (NOAL, 2010).

A coleta de dados foi efetivada mediante o envio de um questionário com perguntas fechadas e abertas para os tutores que atuam no Curso, sendo realizada entrevista com a coordenadora, com o coordenador de tutores e com uma liderança que tem 36 anos de convivência com as populações do campo de MS e vários anos como participante em movimentos sociais e sindicais.

O artigo apresenta, resumidamente, a proposta político-pedagógica do Curso, a metodologia de pesquisa com os dados coletados e organizados, algumas análises e reflexões que evidenciam a relação estabelecida entre os tutores e os alunos com a mediação das tecnologias eletrônico-digitais e, por último, as considerações finais.

\section{O CURSO DE ESPECIALIZAÇÃO EM EDUCAÇÃO DO CAMPO/UFMS/EaD}

A UFMS começou a sua história na modalidade da educação a distância no ano de 1991, por meio de ações descentralizadas, movimentadas por grupos específicos, integrando professores das áreas de Matemática, Física, Educação, Ciências Humanas, Química e Biologia 5 . Estes tinham o objetivo de criar um grupo interdisciplinar com o intuito de apoiar os professores das redes públicas com enfoque na formação continuada. Em 2000 foi constituído o grupo Temático de Educação a Distância da UFMS e a Assessoria de Educação Aberta e a Distância, vinculada à Reitoria. Em seguida, a Assessoria foi transformada em Coordenadoria de Educação Aberta e a Distância (CED), atrelada à Pró-reitoria de Ensino de Graduação (PREG). Em 2001 a UFMS foi credenciada para o oferecimento de Cursos de Graduação e Pós-Graduação na modalidade a distância, iniciando com a formação inicial de professores, Curso de Pedagogia.

\footnotetext{
${ }^{5}$ Informações retiradas do site: http://eadserver.ead.ufms.br/wordpress/historico Acesso em: 19 jan. 2016 Educação em Revista|Belo Horizonte|v.36|e215770|2020
} 
Em 2006, com as políticas de incentivo às atividades de EaD implementadas pelo Ministério da Educação (MEC), a UFMS integrou-se ao Sistema Universidade Aberta do Brasil $(\mathrm{UAB})^{6}$, ampliando a oferta de cursos de formação inicial de professores: Pedagogia (séries iniciais); Pedagogia (Educação Especial); Pedagogia (EJA); Letras (Português/Espanhol); Matemática e Administração. A integração da UFSM à UAB possibilitou a ampliação da oferta de vagas e das atividades no AVA e outras mídias (videoconferências, web conferências, utilização de salas virtuais, aulas gravadas e outras disponíveis), sem contar os encontros realizados nos polos de apoio presencial (polos), sob a coordenação dos professores.

O Curso de Especialização em Educação do Campo foi implantado no período em que houve um amplo investimento na $\mathrm{EaD}$, como caminho de interiorização do ensino superior voltado para a formação continuada e sob a coordenação da Secretaria de Educação Continuada, Alfabetização e Diversidade (Secad), criada em julho de 2004, responsável por temas como alfabetização e educação de jovens e adultos, educação do campo, educação ambiental, educação escolar indígena, diversidade étnico-racial. A criação dessa Secretaria foi uma das respostas do governo do PT, conduzido por Luiz Inácio Lula da Silva ${ }^{7}$, a antigas reivindicações dos movimentos populares na busca de diminuir as desigualdades sociais. Em 2011 a SECAD passa a incorporar o termo inclusão (educação especial) e denominar-se SECADI.

A adesão das instituições públicas de ensino superior aos cursos sob a coordenação da SECAD/SECADI e com o apoio financeiro do MEC se deu por meio de Editais. A UFMS participou do Edital No $1 / 2008^{8}$, iniciando a primeira turma do Curso de Especialização em Educação do Campo em dezembro de 2009. Atualmente há três turmas concluídas (2009-2011; 2012-2014; 2014-2016), certificando, no total, aproximadamente 550 alunos.

O Curso, segundo seu Projeto Político-Pedagógico (PPP), está voltado preferencialmente a professores da educação básica, técnicos e gestores que atuam na educação pública do campo, com foco na formação continuada e tendo como objetivos: a) cumprir as Diretrizes Operacionais para a Educação Básica das Escolas do Campo (2002); b) inserir e

\footnotetext{
${ }^{6}$ O Sistema UAB foi criado pelo Ministério da Educação no ano de 2005, em parceria com a ANDIFES e Empresas Estatais, no âmbito do Fórum das Estatais pela Educação com foco nas Políticas e a Gestão da Educação Superior. Trata-se de uma política pública de articulação entre a Secretaria de Educação a Distância - SEED/MEC e a Diretoria de Educação a Distância - DED/CAPES com vistas à expansão da educação superior. Disponível em: http://www.uab.capes.gov.br/index.php/component/content/article?id=9 Acesso em: 18 jan. 2016.

${ }^{7}$ Análises das políticas adotadas pelo governo Lula indicam que este privilegiou algumas questões da agenda da educação superior: ampliação e democratização de acesso; busca de equidade, contemplando populações historicamente não atendidas. A educação a distância, como caminho de interiorização do ensino superior foi uma das prioridades governamentais. (AGUIAR, 2016).

${ }^{8}$ Edital N 1 SECAD/MEC, de 16 de abril de 2008. Chamada Pública para Seleção de Instituições de Ensino Superior para implementação da rede de educação para a diversidade no âmbito do Sistema Universidade Aberta Do Brasil - UAB. Disponível em: http://portal.mec.gov.br/secad/arquivos/pdf/edital1_160408.pdf Acesso em: 19 jan. 2016.
} 
aproximar as populações do campo das ferramentas da comunicação midiática, favorecendo o diálogo com as tecnologias específicas do campo; c) proporcionar reflexão e debate sobre o fazer político-pedagógico nas escolas do/no campo considerando a diversidade do universo camponês, equacionando dificuldades de acesso e de permanência com o objetivo de construir, coletivamente, uma educação básica do campo compartilhada e emancipatória.

A matriz curricular do Curso está organizada em seis módulos nomeados respectivamente como: Educação do campo: introdução, conceitual EaD e ferramenta Moodle; Educação do Campo: trabalho de conclusão de curso, pesquisa e registro de experiências; Educação do Campo: fundamentos filosóficos, históricos, sociológicos, políticos e econômicos; Educação do Campo: políticas públicas e gestão compartilhada; Educação do Campo: concepções, planejamento e práticas político-pedagógicas; Educação do Campo de MS: um projeto em construção (seminário de encerramento com apresentações dos Trabalhos de Final de Curso/TFC).

A metodologia utilizada para o desenvolvimento do curso se caracteriza por ser a distância, contando com encontros presenciais. Os períodos realizados a distância são efetivados via internet, com o auxílio da plataforma Moodle. Salienta-se que, no decorrer do curso, os alunos têm acesso a orientadores acadêmicos (tutores presenciais e a distância) que estão disponíveis para dirimir dúvidas, debater conteúdos e apoiar na elaboração das atividades avaliativas. O Curso tem duração de 18 meses, 360 horas e a realização de doze encontros presenciais, efetivados nos polos, com o objetivo de possibilitar o debate, as trocas, o encontro com diferentes linguagens (teatro, poesia, literatura, música, dança, artes plásticas, manifestações culturais) e a construção coletiva de propostas inovadoras com a educação do campo em MS. O processo de construção do TFC inicia com a entrega da proposta inicial, perpassa todas as disciplinas e é concluído com a entrega do artigo científico e a apresentação oral em Seminário Estadual com o objetivo de problematizar e registrar experiências desenvolvidas em MS para, coletivamente, pensar caminhos com os seus protagonistas para que essa seja, de fato, das populações do campo de MS.

Para além desses encontros nos polos, há encontros em escolas públicas de assentamentos, de aldeias indígenas, de comunidades quilombolas e outros, com a finalidade de proporcionar trocas de experiências envolvendo as teorias estudadas e os saberes do campo no contexto das escolas. Devido às dificuldades enfrentadas no acesso às tecnologias eletrônicodigitais, o PPP propõe flexibilidade maior, possibilitando o intervalo de um mês entre a finalização de um módulo e o início de outro, para que os alunos possam atualizar atividades avaliativas que, por algum imprevisto, não tenham sido realizadas e postadas. Com essa proposta espera-se que o Curso consiga proporcionar um processo significativo de formação continuada 
que valorize e que provoque o diálogo dos saberes do campo com os demais saberes produzidos no mundo.

\section{CAMINHOS METODOLÓGICOS}

A pesquisa manteve predominância qualitativa, com a intenção de privilegiar a busca dos significados e das subjetividades (MINAYO, 1996; 1999). Sendo de caráter descritivo, que, segundo Negrine (1999, p. 61), está apoiada: “[...] na descrição, análise e interpretação das informações recolhidas durante o processo investigatório procurando entendê-las de forma contextualizada.". Portanto, os fenômenos são apresentados sem a preocupação de generalizar os dados e tampouco de inserir variáveis no cotidiano investigado, mas, sim, de perceber as sutilezas, delicadezas, conflitos e significados que fazem parte do contexto estudado (MINAYO, 1996, 1999; GOLDENBERG, 1998).

O instrumento utilizado na coleta dos dados foi um questionário misto com perguntas fechadas e abertas, com a intenção de proporcionar aos professores participantes a oportunidade de escrever mais livremente sobre o tema proposto (MARQUES et al, 2014; GOLDENBERG, 1998). Esse foi composto de vinte e duas questões, sendo que desse total doze foram em relação aos dados de identificação e dez relacionadas a informações sobre os alunos do Curso, mais especificamente sobre a relação ao acesso e ao domínio no uso de tecnologias eletrônico-digitais. O contato e o pedido de preenchimento do questionário foram realizados via e-mail, devido ao período de recesso em que a coleta foi realizada (dezembro/2015 e janeiro/2016), no qual seria difícil o encontro pessoal com os sujeitos envolvidos na pesquisa. Também foi enviado, por e-mail, um questionário com duas perguntas mais amplas para uma liderança do campo, concluinte da turma 2009-2011, com o intuito de obter informações de alguém que nasceu e viveu no campo, entre acampamentos e assentamentos. As entrevistas foram realizadas pessoalmente, com a coordenadora do Curso e o coordenador de tutores, após o retorno dos seus períodos de férias. Os participantes da pesquisa, quinze tutores, dois coordenadores e duas lideranças, se constituíram em informantes-chave, pois são profissionais envolvidos com os processos de ensino e de aprendizagem, possuindo significativa experiência com o grupo de alunos e condições de discorrer sobre o trabalho que desenvolvem. Salientamos que todos os participantes concordaram em participar da pesquisa e foram informados de que os dados seriam utilizados para fins acadêmicos.

A organização e a análise dos dados foram realizadas por meio da hermenêutica dialética proposta por Minayo (1999), método de abordagem qualitativa, na busca de superar a lógica positivista e de enquadramento das respostas em categorias preestabelecidas. Nessa concepção teórico-metodológica, as respostas são apresentadas na íntegra, mas com alguns recortes, respeitando a redação de cada participante e sem a busca de interpretações e 
interferências externas por parte das pesquisadoras. Ao final, foi efetivado um apanhado geral que possibilitou algumas conclusões. A abordagem hermenêutica possibilitou a transcrição das respostas na busca intencional de que os diferentes participantes se sentissem contemplados. A abordagem dialética permitiu a identificação de algumas contradições e a possibilidade da análise crítica.

\section{DIALOGANDO COM OS SUJEITOS}

O diálogo da hermenêutica com a dialética se constituiu em um significativo caminho para fundamentar a organização e a análise dos dados coletados por meio dos questionários e das entrevistas. Foram enviados questionários para vinte e um tutores e tivemos a devolutiva de quinze deles, com o seguinte perfil':

\begin{tabular}{|c|c|c|c|c|c|c|c|c|}
\hline \multirow[t]{2}{*}{ Nome } & \multirow{2}{*}{$\begin{array}{l}\text { Idade } \\
\text { (anos) }\end{array}$} & \multirow{2}{*}{$\begin{array}{l}\text { Viveu/vive } \\
\text { no campo }\end{array}$} & \multirow{2}{*}{$\begin{array}{c}\text { Trabalha } \\
\text { no } \\
\text { Campo }\end{array}$} & \multicolumn{2}{|c|}{ Escolaridade } & \multirow[t]{2}{*}{ Profissão } & \multirow{2}{*}{$\begin{array}{c}\text { Tempo } \\
\text { de } \\
\text { serviço } \\
\text { (anos) }\end{array}$} & \multirow{2}{*}{$\begin{array}{c}\text { Tempo } \\
\text { tutor } \\
\text { campo } \\
\text { (anos) }\end{array}$} \\
\hline & & & & Concluída & Cursando & & & \\
\hline Afonso & 51 & Não & Não & Mestrado & Doutorado & Serv. Público Federal & 22 & 2,5 \\
\hline Beatriz & 28 & Não & Não & Mestrado & & Professora Teatro & 02 & 01 \\
\hline Carla & 35 & Sim & Não & Especialização & & Professora & 07 & 01 \\
\hline Carmem & 51 & Sim & Sim & Mestrado & & Professora & 12 & 04 \\
\hline Francisco & 64 & $\operatorname{Sim}$ & Não & Doutorado & & Professor universitário & 27 & 03 \\
\hline Ilma & 59 & Sim & Não & Mestrado & & Professora & 20 & 03 \\
\hline João & 35 & Não & Não & Doutorado & & Professor & 16 & 4,5 \\
\hline Lucia & 60 & Não & $\operatorname{Sim}$ & Mestrado & & Professora & 30 & 04 \\
\hline Luciana & 49 & $\operatorname{Sim}$ & Não & Especialização & Mestrado & Professora & 20 & 06 \\
\hline Manuela & 35 & $\operatorname{Sim}$ & Não & Mestrado & & Professora & 16 & 01 \\
\hline Monica & 44 & $\operatorname{Sim}$ & $\operatorname{Sim}$ & Especialização & & Professora & 28 & 01 \\
\hline Rafael & 41 & $\operatorname{Sim}$ & Não & Mestrado & & Serv. Público Federal & 21 & 01 \\
\hline Renato & 52 & Sim & Não & Mestrado & & Professor & 30 & 04 \\
\hline Vanessa & 42 & Não & Não & Mestrado & & Professora & 15 & 02 \\
\hline Xavier & 44 & $\operatorname{Sim}$ & Não & Mestrado & Doutorado & Professor & 18 & 03 \\
\hline
\end{tabular}

Em uma breve análise dos dados apresentados, destacamos os níveis de escolaridade concluídos ou cursando, mestrado (11) e doutorado (quatro); o quantitativo que viveu ou vive

\footnotetext{
${ }^{9}$ Os nomes utilizados são fictícios com a intenção de preservar a identidade dos participantes.
} Educação em Revista|Belo Horizonte|v.36|e215770|2020 
no campo (10); a média de idade (42 anos) e a média do tempo de atuação profissional (19 anos). Apesar do tempo de tutoria no Curso não ser alto, os dados evidenciam a consolidação da equipe, pois um tutor atua há seis anos, tendo acompanhado as três turmas, nove começaram a atuar na segunda turma e os demais são egressos da turma 2012-2014, o que indica que há uma identificação com a proposta do Curso, conhecimento e experiência que asseguram fidedignidade às respostas. No entanto, é importante destacar que dos 11 tutores que viveram no campo, somente dois continuam atuando neste espaço, dados esses que indicam que as pessoas que saem do campo para estudar geralmente não retornam, embora mantenham uma forte conexão com essas temáticas.

De maneira mais detalhada sobre as formações iniciais e continuadas, temos a predominância de licenciaturas, alguns com mais de uma área de formação: História, Ciências Biológicas, Matemática (3); Pedagogia (6); Administração; Direito; Geografia (3) e Filosofia. As especializações são diversificadas, sendo que a maioria tem mais de uma (Ensino e Aprendizagem em Educação Matemática; Educação do Campo (3); Gestão de Políticas Públicas; Planejamento; Implementação e Gestão de EaD; Matemática Superior; Mídias na Educação; Ciência da Computação; Gestão Escolar; Magistério nas Séries Iniciais; Psicopedagogia (2); Planejamento Urbano e Ambiental; Metodologias e Gestão para a Educação a Distância; Ciências Sociais; Planejamento Educacional; Metodologia do Ensino de História; Gestão em Políticas Públicas; Gênero e Raça). Essa é uma tendência, pois a busca pela formação continuada se fortaleceu nos últimos anos pela ampliação das ofertas, pela fragilidade da formação inicial e pela busca de adequação ao mundo do trabalho (GATTI; BARRETO, 2009).

Ainda nesta etapa de apresentação foram questionados se o exercício das suas profissões, que não a tutoria, está diretamente relacionado com o uso de tecnologias eletrônicodigitais. Os quinze participantes responderam que sim, dado que indica que o uso dessas tecnologias faz parte do cotidiano da maioria dos profissionais que atuam em educação, seja na Educação Básica, seja no Ensino Superior. Ao justificarem as suas respostas, assim se manifestaram:

Trabalho com Educação a Distância na UFMS e o doutorado é na mesma área. Integro grupo de pesquisa sobre TDICs (Tecnologias Digitais de Informação e Comunicação) na Educação. (Afonso)

Trabalho a 12 anos no Núcleo de Tecnologia Educacional de Campo Grande, [....] Nossa função é assessorar, acompanhar e avaliar os trabalhos que envolvem o uso de várias tecnologias e mídias em sala de aula. (Luciana)

Sim, porque além de ser um meio do qual utilizo a ferramenta tecnológica para programar, planejar e organizar as aulas que serão ministradas, é um elemento de divulgação do resultado da mesma que, por sua rapidez, reforça comunicados e avisos que favorecem o processo do trabalho. (Beatriz)

Após essa breve apresentação do perfil do grupo de tutores, passamos a expor a opinião dos mesmos sobre a formação a distância voltada aos educadores do campo. Foi 
perguntado sobre a qualidade dos equipamentos eletrônico-digitais, aos quais os alunos do Curso sob as suas tutorias têm acesso, considerando as características de memória, velocidade, atualização, quantidade de equipamentos em relação ao número de pessoas que utilizam e outros aspectos característicos de cada grupo. As respostas foram diversificadas e se justificam pelo fato de o Curso ser desenvolvido em diferentes municípios de MS, que apresentam variável qualidade de acesso a equipamentos e ao sinal de internet, considerando que os polos são equipados e mantidos pelas administrações municipais:

Isso depende da localização e estrutura do assentamento/farenda/comunidade. Nas que já tive oportunidade de atuar, os cursistas, na maioria das vezes, precisavam se deslocar até a sede do municipio para trabalhar nas atividades do curso. Algumas escolas do campo disponibilizam internet, mas nem sempre de qualidade. A conexão por telefonia celular, nessas áreas, costuma ser precária. (João)

Muito poucos alunos do Curso Educação do Campo têm internet em casa através do telefone e modem. É um pouco mais comum a internet através do celular, mas o sinal (mesmo dos provedores de maior alcance), nem sempre é bom. O aluno tem muita dificuldade para o acesso às mídias. Os municípios que dispõem as salas com internet nos polos, por um lado facilitam o acesso, mas por outro o aluno necessita se deslocar de seu ambiente familiar para ir à sala do polo. Isto demanda tempo e recursos para deslocamento e transporte. Alguns alunos, que são professores, têm acesso aos equipamentos eletrônico-digitais nas escolas onde atuam, mas nem sempre têm sinal de qualidade. (Francisco)

A qualidade excelente refere-se aos equipamentos conservados, aparentemente novos, ambiente climatizado, quantidades e acomodação de lugares adequável sendo este local um laboratório do Curso de Matemática (UFMS) que possibilita a manutenção e resolução de problemas técnicos favorecendo o bom acesso nesse sentido. (Beatriz)

O Moodle é o software de acesso aos materiais de apoio e para a realização das atividades avaliativas, mas ainda apresenta algumas dificuldades para os alunos que não utilizam a internet em seus cotidianos:

O moodle é uma plataforma tranquila para utilizarmos, do ponto de vista do tutor, mas do cursista ainda é problemático. Muitos utilizam esta plataforma pela primeira vez, tornando o contato muito emblemático. Neste sentido, a participação do tutor presencial torna-se muito importante. Precisa ser cauteloso e paciente em explicar diversas vezes como navegar em cada espaço da plataforma. (Xavier)

As respostas apresentadas indicam a diversidade dos contextos existentes entre os discentes do Curso e as diferenças de acesso aos equipamentos e ao Moodle, de região para região e de aluno para aluno. MS é um Estado de baixa densidade demográfica, constituído por municípios de pequeno porte, afastados geograficamente uns dos outros e com realidades sociais, econômicas e culturais diversificadas (FIALHO, 2014), o que resulta em diferentes condições de acesso e uma desigual inclusão digital que fica evidenciada nas respostas dos tutores:

As escolas do campo têm várias tecnologias, mas muitas estão sem condições de uso, algumas obsoletas, outras não estão sendo usadas por desconbecimento tecnológico. Os professores não têm equipamento próprio para continuar o acesso nas horas atividades na escola ou fora dela. É uma inclusão dentro de exclusão. (Luciana)

Em partes porque a inclusão compreende a autonomia do aluno em relação à tecnologia e o aprendizado recebido minimamente sobre a tecnologia utilizada. (Beatriz) 
Acredito que o acesso pleno e sem interrupcõos é indispensável para uma educação de qualidade. Contatei que é muito difícil o professor/aluno conseguir acessar conteúdo de vídeos, devido à lentidão da internet. Uma via de aprendizagem fica prejudicada. (Rafael)

Em partes porque a inclusão compreende a autonomia do aluno em relação a tecnologia e ao aprendizado recebido minimamente sobre a tecnologia utilizada. (Beatriz)

As dificuldades, além do acesso aos equipamentos e à internet, também estão relacionadas ao pouco domínio de alguns alunos para utilizar essas ferramentas, mas compreendemos que essa inclusão se faz no processo, que a atuação dos tutores é fundamental e que o Curso está contribuindo e desmistificando o acesso a essas tecnologias:

[...] ainda encontram muitas dificuldades para desenvolver as atividades, fazer pesquisa e ler adequadamente os conteúdos propostos. (Francisco)

Estão sim contemplados com a inclusão nas tecnologias eletrônico-digitais, mas eles ainda precisam estar mais preparados para estudarem nessa modalidade. Inicialmente o curso, por ser a distância, $e$ precisar do minimo de dominio na internet, alguns alunos pensaram em desistir. Contudo, procurei apresentar de forma simples como acessar, onde encontrar o material, realizamos esse processo juntos várias vezes, dando a oportunidade de perguntas e questionamentos. Hoje, na plataforma, têm acesso ao que precisam. (Monica)

No entanto, o irregular acesso à internet é a dificuldade apontada com mais frequência, considerando que a qualidade de sinal disponível ainda é precária, tornando-se caótica quando acontecem eventos nos municípios que aumentam o número de usuários ou quando ocorrem fenômenos naturais, como chuvas fortes e outros. Essa situação é assim explicada pela coordenadora do Curso:

$O$ acesso à internet é bastante irregular e restrito, impedindo que se mantenha a mesma qualidade em todos os polos de apoio presencial. Nos municipios de maior porte ou localizados nas proximidades de cidades maiores (Campo Grande, Paranaíba, Rio Brilhante, São Gabriel do Oeste e Três Lagoas) há menor indice de problemas, mas nos municipios de fronteira, de menor porte ou que estão cercados por montanhas (Bela Vista, Costa Rica e Ponta Porã), esse acesso se torna quase caótico, prejudicando a qualidade do Curso. Tentamos diminuir essas dificuldades com a gravação de videoaulas, mas, muitas vezes, os equipamentos dos alunos não conseguem fazer o download. Nesses casos sugerimos aos tutores que organizem encontros presenciais na sede dos polos ou em outros locais que ofereçam melhores condiçoes. No entanto, quando ocorre algum evento no município, como o caso de festas populares e rodeios, a rede fica sobrecarregada o que já exigiu alteração no calendário do Curso. (Clara)

Esse contexto da internet também fica evidenciado nas respostas de alguns tutores, quando perguntados sobre as principais e mais frequentes dificuldades apresentadas pelos alunos para acompanharem o Curso:

O maior problema sempre foi a qualidade do acesso à internet e, em parte por decorrência disso, a subutilização do Moodle. (Afonso)

Falta de internet no campo. Dificuldade de encontro entre os cursistas (para atividades em grupo) em função da distância de deslocamento para realização de atividades. Condições precárias para deslocamento em dias de chuva, para participação nos encontros presenciais e, consequentemente, acompanhamento das atividades do curso. (João)

A falta de internet no campo que, geralmente, é de péssima qualidade. A insuficiência do domínio técnico das TDICs, principalmente da Internet, de alguns alunos, cria e dificuldades em acompanhar as atividades. Mas no decorrer do curso as dificuldades são sanadas e todos conseguem realizar as atividades contemplando os objetivos. (Carmem) 
No entanto, as dificuldades para acompanhar o curso e construir uma formação significativa e de qualidade estão para além das questões tecnológicas (FREITAS, 2010). Os alunos do Curso, assim como a média dos alunos brasileiros, apresentam lacunas em suas formações, principalmente relacionadas com a leitura, a interpretação e a escrita. A formação a distância exige disciplina e autonomia do aluno para estudar, mas muitas vezes essas características são frágeis ou inexistentes:

A dificuldade maior é por parte dos próprios alunos, na questão de leitura e interpretação. Há pouco entendimento do que se pede. (Lucia)

A maioria dos alunos tem dificuldade para elaborar as atividades de forma técnica dentro das normas exigidas. Fazem as pesquisas, mas no momento de transcrever seus pensamentos e opiniões, encontram dificuldades em elaborar suas ideais no foco da pesquisa. (Renato)

Aparentemente, tenho a impressão que não há uma rotina em verificar os e-mails enviados, acredito que esta verificação de e-mails deve ser uma prática de quem estuda e orienta na EaD. Muitos alunos demoram em nos dar retorno as orientacóes e questionamentos e desta forma, temos que utilizar contatos via telefone quando temos urgência nas respostas. (Xavier)

Não tem acesso a internet nas escolas do campo. Nos polos tem internet, mas a velocidade é baixa, não conseguem assistir uma webconferência com áudio bom; com a velocidade baixa não conseguem fazer downloads de materiais como, por exemplo, vídeos, pdf, apostilas. Nas escolas os materiais didáticos são descontextualizados da realidade do povo camponês. Sua formação inicial e continuada foi desvinculada da realidade do campo com pouca base teórica, precisam se esforçar muito para fazer pesquisas. A indicação dos gestores administrativos e pedagógicos é feita por questões políticas e, muitas vežes, os indicados não têm formação adequada para colaborar com os professores que saem da formação e querem aplicar seus conbecimentos nas aulas. Falta de incentivo financeiro para o deslocamento da escola do campo até os polos dos encontros presenciais. Carga borária extensa com pouco tempo para os estudos e planejamento. (Luciana)

O percurso de qualidade exige o acesso a Internet em suas casas ou em lugar mais favorável que não exigisse o deslocamento para a sala do polo durante a semana. A formação recebida nos seus processos de ensino fundamental, médio e superior tem muitas lacunas, principalmente no que se refere à compreensão do texto. Muitas vezes não conseguem compreendera a ideia do autor. Dificuldade na escrita, na estruturação, comunicação das ideias e correção do texto. Não valoriz̧ação do conhecimento já adquirido ou dos saberes do campo, há preconceito com o modo de viver do campo. Não conbecimento e muito menos dominio da pesquisa virtual. A riqueza de conteúdo e as informações disponiveis na internet não são acessadas por não conbecerem os caminhos para chegar a eles. Para desenvolver o Trabalho de Final de Curso (TFC) apresentam dificuldades com o referenciamento das fontes de pesquisa. Medo de se expor e dizer o que pensam. Acham que não têm o que dizer de novo. No entanto a sua experiência do dia-a-dia tem uma grande contribuição e riqueza a ser comunicada. (Francisco)

Esses contextos, tão complexos da formação na modalidade a distância, dialogam com a afirmativa de Freitas (2010, p. 340):

Tenho observado, por meio de nossas pesquisas, que escolas equipadas com computadores e acesso à internet e professores egressos de cursos básicos de informática educativa não têm sido suficientes para que se integrem os recursos digitais e as práticas pedagógicas. Se o desejável é que os professores integrem computador-internet à prática profissional, transformando-a para melhor inseri-la no contexto de nossa sociedade marcada pelo digital, é preciso ir muito além. [...] A revolução tecnológica introduz não só uma quantidade enorme de novas máquinas, mas principalmente um novo modo de relação entre os processos simbólicos que constituem o cultural. 
No entanto, é essencial destacar o processo de acompanhamento da atuação dos tutores que participam de reuniões mensais para estudar, apresentar as dificuldades e socializar alternativas de solução. Essa busca coletiva tem alcançado resultados interessantes que se efetivam no processo de comunicação construída com criatividade e persistência, recorrendo às redes sociais, aos e-mails particulares e outros recursos, principalmente criação de grupos via Facebook e Whatsapp na busca pela participação dos alunos:

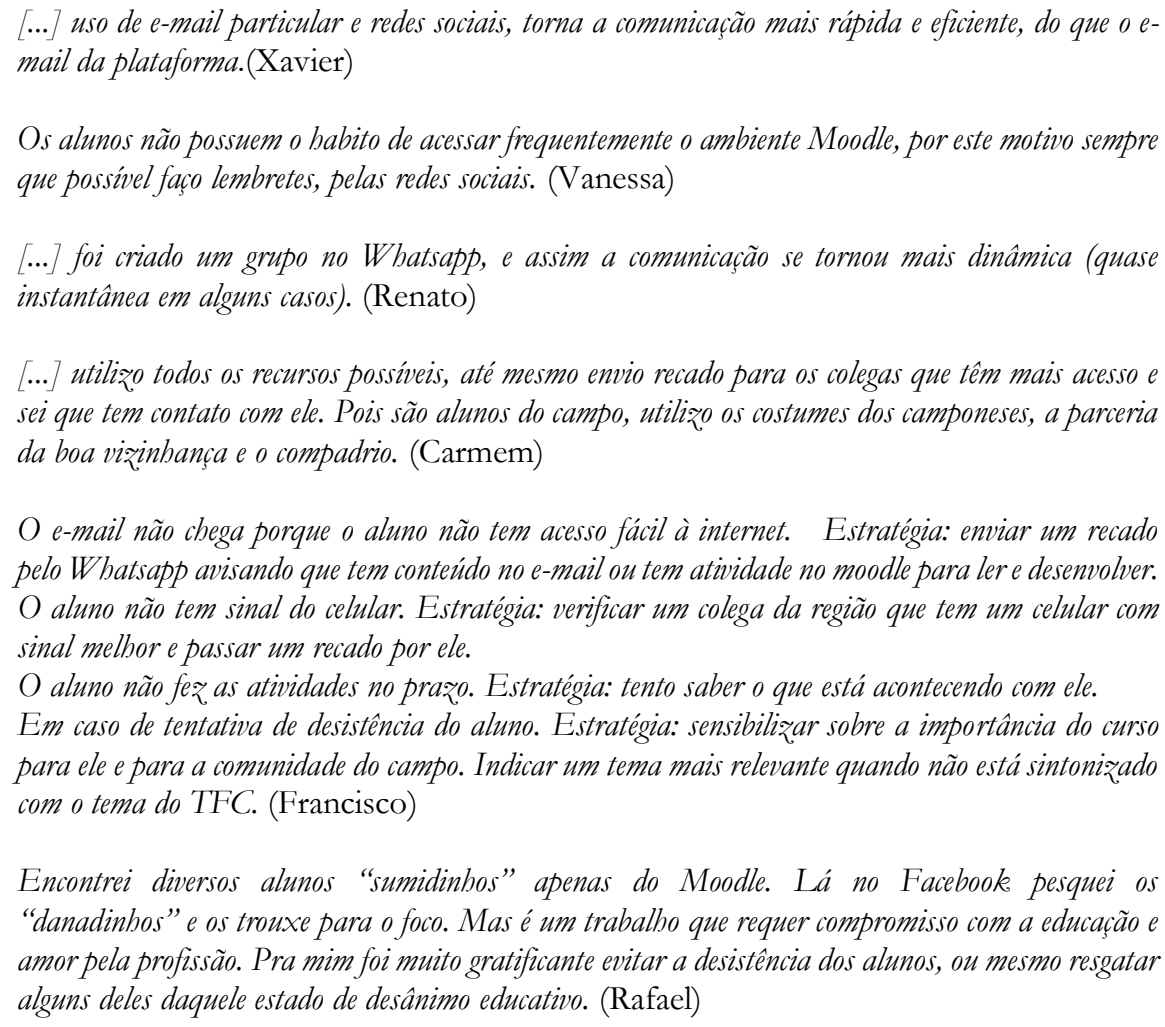

A coordenadora do Curso também enfatizou as características peculiares do grupo de alunos, principalmente os que residem e trabalham no campo, e algumas estratégias políticopedagógicas assumidas intencionalmente, na busca de diminuir os índices de evasão, tais como: flexibilização do calendário, ampliação dos prazos para postagem das atividades avaliativas e não fechamento do Moodle; visitas aos locais de moradia e de trabalho; distribuição gratuita de livros impressos para todos os alunos; criação do lema coletivo "nenhum aluno a menos". Essa proposta se confirma na afirmação da tutora Carmem: “[...] muitas das vezes servimos de apoio para os alunos, quando apresentam problemas nos seus cotidianos, parece que somos distantes, mas estamos muitos próximos deles."

No caso específico do Moodle, é importante compreender que esse é um recurso didático largamente utilizado em cursos na modalidade a distância, possibilitando o acesso aos materiais disponibilizados pelos professores, como também participar de chats, fóruns, postar atividades avaliativas e outros. Esse acesso, via internet, exige equipamentos que assegurem navegar com segurança, agilidade e constância. Também requer uma certa familiaridade com a comunicação online, habilidade que alguns alunos não evidenciam, pois quando residem no 
campo, só têm acesso quando se deslocam para outros locais, na maioria das vezes distantes de suas residências. Essa falta de uso cotidiano acarreta dificuldades pessoais que, somadas às outras, acabam tornando ainda mais complexos os processos de ensino e de aprendizagem. $\mathrm{O}$ coletivo de professores e tutores, ciente dessas dificuldades, procurou, intencionalmente, facilitar esse percurso por meio de estímulo ao uso do computador durante os encontros presenciais, bem como na valorização das experiências vividas no campo e manifestadas pela oralidade. Dessa maneira, as práticas político-pedagógicas presenciais buscaram valorizar outras linguagens, de domínio dos alunos, para que esses sentissem maior segurança e liberdade para experimentar, perguntar, pedir ajuda.

Nessa busca de contato e de maior aproximação com os alunos, aparecem algumas dificuldades de comunicação que se constituem como fatos curiosos e pitorescos que evidenciam os desencontros e os encontros da formação na modalidade a distância. Em alguns casos, os próprios usuários buscam estratégias inusitadas de acesso, em outros, percebe-se que ainda há muito desconhecimento sobre as tecnologias eletrônico-digitais que, contadas, parecem irreais. É interessante constatar que somos todos suscetíveis aos equívocos frente a equipamentos desconhecidos, pois, como adverte Junqueira (1999, p. 64): “Quando alguém entra em contato com costumes diferentes, que não consegue compreender, sua primeira reação é fazer comparações, tomar por base a própria cultura, numa tentativa de organizar a informação a partir daquilo que conhece." Com as populações do campo e com os alunos do Curso, não tem sido diferente:

Acompanhei diversos momentos da introducão do universo digital na vida cotidiana, desde 1986, quando comprei meu primeiro computador até os dias de hoje. São experiências ricas da iteração entre pessoas e esses equipamentos. Lembro de dois professores doutores da UFMS (anos 1980) maravilhados com o fato de que, ao digitar em um processador de textos, as palavras escritas "iam sozinhas" para a linha seguinte quando ultrapassado o limite...

Outra professora reclamou para mim uma vez (anos 1990) que o "controle remoto" do computador não estava funcionando (segurava um mouse como se fosse um controle remoto).

E quando eu entrei com um notebook em sala de aula (anos 1990) uma professora, também doutora, perguntou se o que ela falava ficava escrito ali (no computador). Eu respondi que sim, desde que en digitasse...

E são muitos casos como esses, muitos registrando o estranhamento de pessoas notáveis, com alto nível de conbecimento e estudo. Claro que esse tempo passou, pois os artefatos digitais já foram incorporados à cultura da maioria da sociedade e incorporados ao dia a dia das famílias. Hoje, novos horizontes se impõem e, de certa maneira, todas as pessoas já têm algum conbecimento ou convivência com a cultura digital. (Afonso)

Subir ao morro para pegar o sinal de celular. (João)

Um fato curioso que me aconteceu foi quando estava andando de carro por uma rodovia e visualizei um radar, diminui a velocidade e passei, mais para frente fui parada pelo agente polícia que me multou, dizendo que eu havia ultrapasso a velocidade limite da rodovia, assinei a multa e ele logo me liberou, segui o men percurso, mais a frente o carro parou, fiquei sem saber o que tinha acontecido. Chamei o seguro, quando chegaram fizeram uma avaliação e disseram que a injeção eletrônica do carro tinha paralisado. Ou seja, o velocímetro estava parado, não funcionava e o medidor do nivel de gasolina também não. Fui multada e a gasolina acabou. Fui enganada pelo medidor. (Luciana)

Quando foi perguntado a uma professora se ela conbecia o Moodle, ela respondeu que não, que só entendia de libras. Não sabia o que era Moodle, entendeu "mudo". (Lucia)

Educação em Revista|Belo Horizonte|v.36|e215770|2020 
Um fato interessante foi a primeira aula da especialização. Depois que terminamos de explicar tudo sobre como acessar o ambiente moodle, como postar as atividades, enviar e-mail, enfim, a pessoa pergunta como iria digitar a atividade nesse ambiente. A pessoa achava que iria digitar direto no Moodle e não primeiro no Word.

Entre atrapalhações e aprendizagens, é inegável que as populações do campo têm habilidades e se motivam frente a novas possibilidades de alfabetização digital:

Trabalho como Coordenadora Pedagógica da Educação do Campo e um de nossos maiores desafios é a permanência dos alunos que moram no campo nas escolas, outro é trazer a comunidade para participar de ações no ambiente escolar. Após a implantação de salas de tecnologias dentro das escolas do campo o interesse foi coletivo, alguns nunca tinham tido contato com a máquina, os olhos brilhavam ao verem tudo o que podiam fazer, a partir desse momento a frequência as aulas aumentou e o interesse dos pais em vir para a escola também. Inclusive uma das mães atualmente é voluntária na sala de tecnologia. (Monica)

Uma das perguntas do questionário, denominada "Tribuna Livre", provocou cada tutor para registrar alguma insatisfação sua com as políticas públicas de inclusão às tecnologias eletrônico-digitais voltadas às populações do campo. As respostas indicam que a inclusão digital chegou somente em parte aos campos de MS, apesar de haver salas de informática e equipamentos disponíveis. Há muitas dificuldades de manutenção, pouco domínio técnico e quase inexistente acesso à internet, como evidenciam as respostas dos tutores:

A população do campo, embora tenha adquirido diversas conquistas sociais nos últimos anos, ainda são esquecidas no que se refere ao avanço da tecnologia e infraestrutura para a educação. Lamentavelmente, deixam o campo para obter melhores condições de vida na cidade, mas o déficit que tiveram na vida campesina, atrapalham a posição no mundo trabalho e as conquistas futuras. (João)

Temos no Brasil leis especificas que orientam a modalidade EaD, mas que infelizmente não funcionam como deveria. Há uma política em que os estados e municípios são responsáveis para instalar os instrumentos que irão levar o sinal as regiōes mais afastadas e alguns desses municípios simplesmente não instalam estes equipamentos, dificultando o contato com professores e cursistas. Outra questão: quem é o professor na EaD? O professor/conteudista, o professor/formador, o tutor a distância, o tutor presencial? Quem ensina na EaD? Todos podem ser alunos na EaD? Todos podem ser professores na EaD? Para pensarmos um pouco... (Xavier)

As politicas de educação do Campo são recentes no Brasil, embora o país tenha a sua origem fundamentada na agricultura em boa parte de sua história. Essas políticas públicas quando chegam ao campo, apresentam-se na escola como a extensão da escola urbana, no que dir respeito aos curriculos, aos professores e à gestão. No primeiro momento dão mais importância ao agronegócio e ao latifúndio em razão do modelo econômico que se estabeleceu no Brasil. A vida dos professores no campo não é fácil, eles sentem a falta de valorização do trabalho docente, falta de infraestrutura, poucas capacitações e o esquecimento por parte do Estado. Contudo, é preciso enfrentar os desafios de uma Educação do Campo contextualizada, particularmente destinada a fortalecer a agricultura familiar em diferentes modelos, superando a ideia de que a cidade é superior ao campo. É preciso propor ações conjuntas de colaboração e cooperação entre as três esferas do Poder Público (União, Estados e Municipios), com a finalidade de se expandir a oferta de Educação do Campo que viabilize a permanência das populações rurais no campo. (Luciana)

Acredito que as politicas devem incentivar e valorizar mais as novas ferramentas de ensino, mas não apenas para reduzir custo. É preciso saber a importância do uso e o momento. (Rafael)

Já vi uma sala de tecnologia com internet via satélite (doada pelo governo federal) para uma comunidade do campo em Bela Vista ser "esquecida" por três anos. Até o monitoramento chegar e mandar instalar a sala de tecnologia. Falta comprometimento com as políticas. Das mais simples, como o sistema municipal de educação efetivar o direito de formação continuada aos profissionais da educação do campo, onde deveriam contemplar a inclusão digital nas escolas. (Manuela) 
Nossas escolas do campo ainda são desassistidas para a implantação de acesso às tecnologias, internet principalmente. Sala de tecnologia até existe, mas tudo off-line. O campo ainda continua ficando para trás, um tanto quanto esquecido. (Carla)

Há projetos que visam a implantação de salas de tecnologia nas escolas do campo, mas nem sempre isso acontece. E, quando acontecem em alguns lugares o abandono é geral. Internet "fraca" e se alguma máquina apresenta problema não há um técnico disponivel para os ajustes necessários. (Monica)

As contradições existentes em MS, com relação ao acesso às tecnologias eletrônicodigitais, tendo como parâmetro o Curso de Especialização em Educação do Campo/UFMS/EaD, ficam bastante evidentes na manifestação de uma liderança do campo, professor há seis anos, aluno concluinte da primeira turma (2009-2011), mestrando em Educação e que viveu os seus 36 anos de idade nos campos de MS e na afirmativa de Ana, também liderança, com 40 anos de idade e 20 anos de magistério, oriunda de acampamentos e assentamentos, aluna concluinte da segunda turma (2012-2014):

Hoje o Governo Federal desenvolve diversas politicas/projetos para atender as populações do campo, no entanto, nem todas as comunidades recebem tais politicas.

Com relação às tecnologias educacionais ainda estamos atrasados, pois enquanto todas as escolas urbanas possuem uma sala de tecnologias equipadas [...], no campo a realidade muda.

Nas duas escolas do campo localizadas no município, há salas de tecnologias, mas somente a escola municipal tem acesso à internet. A escola estadual não tem acesso a internet, pois o governo do estado de MS justifica estar aguardando o Governo Federal contemplar as escolas. Neste sentido, a escola estadual fica dependente da política nacional, enquanto o governo do estado não desenvolve nenhum projeto para atender as escolas do campo. Percebe-se que no "chão da escola" a realidade muda, pois a sala de tecnologia conta com poucas máquinas para os alunos utilizarem. Os computadores são eproinfo do Campo $^{10}$ e não oferecem internet para acessar sites, realizar pesquisas etc. A escola conseguiu colocar a internet por meio da Associação de Pais e Mestres, no qual efetuam o pagamento mensal, pois a Secretaria do Estado de Educação não permitiu a instalação da mesma e com isso não arca com as despesas.

Mesmo diante de uma tecnologia que está avançando a cada dia, o povo camponês ainda continua sem acesso a diversas tecnologias. As escolas do campo ainda precisam ter acesso a equipamentos e a uma internet de qualidade. (Pedro)

Digo, de todo o coração, que o Curso é uma porta que se abriu e que jamais poderia ser fechada para os povos do campo, sabendo que têm essa dificuldade de acesso à internet deveria ter mais as atividades presenciais e que as atividades a distância fossem mais simples. (Ana)

Tendo como pano de fundo as respostas até aqui apresentadas, exponho a opinião dos tutores sobre a educação na modalidade a distância como opção para a formação de professores de escolas do campo e de outros profissionais, ressaltando que, apesar das dificuldades e limites detectados, é um caminho de formação significativo e possível de ser desenvolvido com as populações do campo de MS. No entanto, também fica evidente que os encontros presenciais são necessários e significativos para a qualidade da formação:

Fica muito prejudicada quando acontece em regiões ainda não servidas pela internet, pois isso não permite uma exploração mais abrangente do $A V A$. [...] A especialização em Educação do Campo da UFMS ocorre na modalidade semipresencial e o foco da aprendizagem ocorre na introducão dos módulos, feita presencialmente [...]. (Afonso)

\footnotetext{
${ }^{10} \mathrm{O}$ Ambiente Colaborativo de Aprendizagem (e-Proinfo) é um ambiente virtual colaborativo de aprendizagem que permite a concepção, administração e desenvolvimento de diversos tipos de ações, como cursos a distância, complemento a cursos presenciais, projetos de pesquisa, projetos colaborativos e diversas outras formas de apoio a distância e ao processo ensino-aprendizagem. Disponível em: http://e-proinfo.mec.gov.br/eproinfo/ interativo/ acessar_espaco_sistema/acessar.htm Acesso em: 19 jan. 2016.

Educação em Revista|Belo Horizonte|v.36|e215770|2020
} 
Acredito que a formação continuada na modalidade EaD é um caminho para a especialização dos professores. [...]. É preciso entender que as mudanças neste novo século são rápidas e precisamos estar preparados para acompanhá-las e a modalidade EaD permite esse acompanhamento. (Xavier)

A educação a distância é a melhor oportunidade que apareceu nesses últimos tempos, veio para ficar, para somar com a educação presencial, para colaborar nos tempos modernos, para ultrapassar fronteiras. A EaD é uma inovação na educação, é uma alternativa para produção e divulgação da informação. (Luciana)

A EaD veio para democratizar o alcance a novos conhecimentos e está fazendo isso, possibilitando a ascensão intelectual de muitos, inclusive de professores de escolas do campo. (Lucia)

É fundamental e perfeitamente viável para a maioria dos casos. O conhecimento pode chegar bem mais longe, de forma rápida e totalmente atual. É possivel se comunicar, construir o conbecimento de forma colaborativa. (Rafael)

Atualmente é uma das melhores opcõos para atingir alunos em espaços geográficos distantes, pois a modalidade EAD favorece a interação e a colaboração com uso intenso das tecnologias de informação e comunicação onde professores e alunos estão separados fisicamente. Contribui na execução das atividades propostas em ambientes virtuais de aprendizagem e também ela está se tornando um instrumento fundamental de oportunidades para muitos estudantes. (Renato)

$V i$ muitos mitos e preconceitos serem desfeitos, principalmente sobre os movimentos sociais. Vi muitos sonhos serem retroalimentados para os espaços escolares do campo. Tudo possivel pela modalidade a distância. (Manuela)

É um curso muito intenso, mesmo sendo a distância. No momento que estou com os docentes do campo, nos encontros presenciais, sinto amor, paixão, brilho nos olhos, vida e luta. [...] Tem contribuido muito a maneira como está sendo trabalhado, traz. muito conbecimento e esclarecimento, porque temos ainda muitos professores com a formação da educação rural e ou para trabalhar o ensino que é oferecido para as crianças da cidade. (Carmem)

Vejo como uma alternativa importante, principalmente para cursos que não chegam às cidades e municipios do interior. Todavia, nosso povo ainda tem muita dificuldade, pois são pessoas que gostam da presença da professora e do professor. Vejo que ainda precisamos de aulas presenciais, principalmente para garantir um debate e um diálogo, em problematizar os conceitos centrais da educação brasileira, a formação de professores como instrumentos de transformação da escola e garantir que tenhamos profissionais com senso crítico, capaz de perceber as relações de poder postas na sociedade de classe que temos e o seu real papel na formação de pessoas. (Carla)

Já fiz vários cursos nessa modalidade. Em minha opinião é ideal para quem tem motivação para aprender, ter a disponibilidade de organização de tempo para os estudos é uma das principais vantagens, tendo autonomia para a realização das atividades. Em tempos onde o trabalho ou a família nos impede de frequentar um curso com aulas presenciais, essa modalidade só tem a acrescentar valores na formação profissional de qualquer pessoa. (Monica)

O coordenador de tutores - 63 anos, doutor em Educação e professor universitário

há 29 anos -, também se manifestou favorável a essa modalidade de ensino com essa população específica, assim como a coordenadora do Curso - 62 anos, doutora em Educação e professora da Educação Básica e do Ensino Superior universitário há 42 anos:

Muito importante. Talvez a única oportunidade dentro dos seus contextos. As linhas de pesquisa propostas pela especialização têm muito a ver com dia-a-dia da educação do campo. Os conteúdos e encontros presenciais possibilitam uma formação consistente na educação do campo. (Alberto)

Após a oferta de três turmas e tendo acompanhado muito de perto o desenvolvimento de cada uma, posso afirmar que é possivel tornar o distante, próximo. Sem negar os limites que a formação a distância traz consigo, principalmente com relação ao acesso aos equipamentos e à internet, e sem negar as características da cultura brasileira que é do contato, da presença, das trocas afetivas, posso afirmar que temos conseguido, com esse Curso, uma qualificação do trabalho docente e uma significativa aproximação entre os professores do campo de MS. Impossivel não ficar emocionada, nos Educação em Revista|Belo Horizonte|v.36|e2155770|2020 
seminários estaduais de encerramento, quando chegam caravanas do interior do Estado e, aos poucos, as populações do campo vão preenchendo os espaços da UFMS. Agradeço a cada certificado de especialização que assino porque tenho consciência de que esse aluno vai propagar, como ondas, os conhecimentos construidos e, com certeza, é um conbecimento que se expande e que se compromete com a transformação social. (Clara)

É inegável que os programas sociais implantados e implementados pelas políticas públicas federais dos últimos anos - desde 2003 com o início do primeiro mandato do governo do Partido dos Trabalhadores (PT) - trouxeram avanços e possibilidades às populações do campo (luz elétrica, telefonia, internet, melhoria de estradas e outros). No entanto, esse acesso ainda é excludente e ainda distancia as populações do campo das populações urbanas com relação à inclusão digital, principalmente em MS, região na qual há a predominância de políticas latifundiárias, com grande concentração na posse das terras e manutenção de privilégios que não se estendem aos trabalhadores do campo (ABREU, 2003; ALMEIDA, 2003, 2006, 2008, 2009, 2010; KUDLAVICZ, 2011). Essas diferentes concepções de se relacionar com a terra, como especulação e lucro (latifúndio) ou como lugar de vida (agricultura familiar), que vêm desde os tempos da colonização, ainda não foram problematizadas e pensadas pelas políticas públicas, na via das transformações sociais, como alerta Arroyo (2010, p. 1404):

Uma análise rápida dos projetos de inclusão cidadã revela que não tocam sequer nas formas brutais de produzir os desiguais nas bases materiais do viver, sobreviver, na negação da proteção da vida, do comer, do trabalho, da moradia, da terra e território, da renda, do salário, nem na instabilidade, insegurança e precarização do trabalho. [...] Nessas fronteiras é pensada a educação-inclusão cidadã, secundarizando ou ignorando as tensas relações entre essas dimensões e as relações desses coletivos sociais, cidadãos com o trabalho, a terra, renda, moradia, sobrevivência, justiça, igualdade, emancipação e cidadania. Os limites em que a cidadania é pensada nos projetos enfraquecem a própria relação entre educação, cidadania e inclusão.

Essa preocupação também está presente nas respostas de Pedro, que, por ter nascido em acampamento e ter vivido seus 36 anos de vida como morador do campo e participante de movimentos sociais e sindicatos, apresenta preocupação com relação às tecnologias eletrônico-digitais no campo, embora não seja negado o direito cidadão a esse acesso:

\footnotetext{
Quando falamos em limites e nos riscos, devemos pensar que qualquer cultura que venha sobre a outra pode contribuir, ou então, destruir aprendizados, culturas e saberes. Penso que as tecnologias também são úteis aos camponeses, pois os mesmos não devem viver no anonimato, o que devemos fazer é uma crítica e buscar valorizar a cultura do povo camponês.

A cultura digital deve vir como aliada e que possa contribuir com a população do campo poder conbecer mais sobre a sua cultura, sobre outras culturas. Que as redes sociais possam servir para socializar ideias, experiências, técnicas que possam valorizar a vida no campo, que possa divulgar suas vidas, suas conquistas, suas colheitas etc.

Ainda temos muito que conquistar para que os educandos possam ter acesso a uma cultura digital que contribua para reconhecer a importancia dos povos do campo. (Pedro)
}

As informações obtidas, por meio dos questionários e das entrevistas, permitem afirmar que as tecnologias eletrônico-digitais estão presentes no cotidiano e são caminhos que viabilizam a formação continuada de professores e de moradores do campo em MS. No entanto, os equipamentos e os acessos apresentam diferenças significativas entre as regiões geográficas, entre os municípios e as políticas públicas locais, bem como de aluno para aluno do Curso. 
Essas diferenças geram desencontros, insatisfações e frustrações, ampliando os índices de evasão, que, de acordo com a coordenadora, estão em torno de 40\%. No entanto, também fica evidente que a intencionalidade de inclusão e as relações humanas são fundamentais na mediação dos alunos com as tecnologias eletrônico-digitais, pois a proposta políticopedagógica do Curso, a flexibilização do calendário e a atuação dos tutores se configuram como essenciais ao desenvolvimento da formação continuada por meio da modalidade a distância. Essa constatação dialoga com o poema de Brecht (1898-1956), sobre os homens e as máquinas: "O homem, meu general, é muito útil: sabe voar e sabe matar, mas tem um defeito: - Sabe pensar." Essa constatação se torna evidente no depoimento da liderança Ana quando afirma que: “Alguns alunos [seus colegas] tinham medo de computador e, após iniciar o Curso da EaD, descobriram um mundo maravilhoso do outro lado da tela."

Diante desses encontros e desencontros entre homens e máquinas, em uma sociedade permeada por diferentes interesses, é necessário evidenciar que, como indica Munarim (2010), a Educação do Campo volta-se para o reconhecimento e o fortalecimento dos processos de resistência e de emancipação das populações do campo, que incluem o direito de terem acesso, em seus lugares de moradia, aos processos educativos que incluem escolas, acervos bibliográficos e tecnologias eletrônico-digitais em diálogo com os saberes do campo. Essa concepção conversa com a afirmativa de Munarim $(2014$, p. 92$)$ sobre as escolas do campo e o uso das tecnologias eletrônico-digitais:

\begin{abstract}
Se a dimensão da produção existe para fortalecer um determinado projeto de sociedade, a formação dos professores para o "uso" das tecnologias não deve se resumir apenas ao seu uso em sala de aula, mas também a momentos de reflexão em que eles possam conhecer, compreender e problematizar junto aos estudantes as dimensões políticas e econômicas que estão em jogo na produção dessas tecnologias. Daí a importância de que professores e estudantes saibam buscar informações, participem, produzam conteúdos próprios, planejem ações, incluam essas ferramentas digitais no cotidiano das escolas como mais um espaço de criação e expressão delas e dos sujeitos que com elas interagem. Que crianças, jovens, pais e professores possam utilizar essas tecnologias como um importante instrumento para suas buscas, suas lutas e seus questionamentos.
\end{abstract}

Nessa perspectiva, e na compilação das respostas dos participantes da pesquisa, é possível afirmar que as tecnologias eletrônico-digitais, em cursos de formação continuada de professores, precisam ser apresentadas e utilizadas como caminhos de aquisição de conhecimentos que estão para além dos cotidianos do campo, mas também para registrar os saberes e as experiências vividas nos contextos campesinos, em uma "sociedade em redes" (CASTELLS, 2003). Não devem ser negadas, mas também não devem ser absolutizadas, considerando que a vida acontece em múltiplas expressões e que, portanto, requer diferentes linguagens para se manifestar e ser registrada em memórias que sejam fonte de fortalecimento das lutas que, historicamente, têm sido efetivadas pela posse e na relação com a terra. 


\section{CONSIDERAÇÕES FINAIS}

A pesquisa realizada buscou responder a questionamentos sobre a utilização das tecnologias digitais por parte dos alunos do Curso de Especialização em Educação do Campo, ofertado pela UFMS, na modalidade a distância, no percurso de formação continuada. O objetivo foi de compreender como esses alunos acessam os materiais disponibilizados e como participam das práticas político-pedagógicas desenvolvidas via Moodle. Após refletir sobre os dados coletados, é possível apontar para algumas conclusões, mas também para questões polêmicas que não se esgotam, pois as tecnologias não são neutras e estão diretamente relacionadas com concepções de mundo e de seres humanos, projetos de vida e de sociedade, relações humanas, educação, terra.

Nessa perspectiva, é essencial destacar que a organização da vida cotidiana no campo se faz por traços culturais e por necessidades de sobrevivência, no coletivo e no exercício de mutirões. No entanto, essas organizações também são permeadas por princípios de competição e de exclusão que regem as desigualdades das sociedades capitalistas. O Curso ofertado é, sem dúvida, considerados os limites apresentados, um significativo avanço. No entanto, é também importante reconhecer que as inovações tecnológicas, no campo, apresentam contradições e podem tanto fortalecer os coletivos, como podem aumentar as diferenças pelo acesso diversificado aos equipamentos e à internet. Informação é poder e é preciso, intencionalmente, educar com e para a solidariedade.

O compromisso político nos conduz a perguntas que permanecem: Como assegurar o direito de acesso às tecnologias eletrônico-digitais sem enfraquecer o valor das tecnologias clássicas do campo? Como manter e ampliar o diálogo entre saberes do campo e saberes urbanos? Como evitar o fetiche pelas tecnologias eletrônico-digitais? Essas e outras perguntas precisam estar presentes no cotidiano para que se possa ampliar as experiências, as organizações campesinas e a melhoria da qualidade de vida em todas as suas dimensões.

As comunidades em rede, viabilizadas pelas tecnologias eletrônico-digitais, podem se constituir como caminhos de encontros entre diferentes e distantes grupos sociais, como também podem aproximar iguais e próximos geograficamente, assegurando convivência e trocas. No entanto, dialeticamente, também podem se constituir como meios de alienação e exclusão. Mediante a opinião dos tutores, coordenadores e lideranças, ficou evidente que há essa consciência no coletivo e o esforço, intencional, de não se negar e tampouco se absolutizar as tecnologias eletrônico-digitais.

O equilíbrio e o diálogo de tecnologias se fazem necessários. As mesmas mãos que usam a enxada têm o direito de manusear o moodle, os mesmos olhos que leem um livro impresso querem ler textos digitalizados, os mesmos ouvidos que ouvem pássaros ao amanhecer podem 
ouvir músicas no rádio. A questão essencial é que os moradores do campo tenham a consciência de que são gestados culturalmente, mas também são transformadores e produtores de cultura. Portanto, assim como reviram a terra com o arado, podem fortalecer as suas comunidades com as TDICs, com a compreensão e com o respeito pelos quais grita a fala do agricultor Ciço, registrada por Brandão (1982, p. 179): “Então eu digo 'educação' e penso 'enxada', o que foi para mim. Mão que foi feita pro cabo de enxada acha a caneta muito pesada.”.

Enxada pesada? Caneta leve? Mouse voador? Será? Só a paciência, a delicadeza e a confiança nas possibilidades do devir de cada mulher e de cada homem do campo podem encontrar caminhos outros... Há muito a aprender, há muito a ensinar, há muito a compartilhar, há muito a esperançar, há muito a cirandar... Vamos de mãos dadas?

\section{REFERÊNCIAS}

ABREU, Silvana de. O Mato Grosso do Sul no contexto das políticas regionais de desenvolvimento, Comunicação; Colóquio Internacional de Desenvolvimento Local, Universidade Católica Dom Bosco, Campo Grande, 2003.

AGUIAR, Vilma. Um balanço das políticas do governo Lula para a educação superior. Rev. Sociol. Polit., v. 24, n. 57, p. 113-126, mar. 2016.

ALMEIDA, Rosemeire Aparecida de. Aliança terra-capital em Mato Grosso do Sul: redefinições no campo e na cidade. Anais... VIII Encontro Nacional da ANPEGE, Curitiba, 28 de setembro a 02 de outubro de 2009.

- A territorialização do agronegócio do eucalipto na Região Leste de Mato Grosso do Sul e o cerco à Reforma Agrária, Texto apresentado no XVI Encontro Nacional de Geografia/ENG, em Porto Alegre - 25 a 31/07/2010

. O conceito de classe camponesa em questão. Revista Terra Livre, São Paulo: AGB, ano 19, V. 2, N. 21, p. 73-78, 2003

. (Re)criação do campesinato, identidade e distinção: a luta pela terra e o habitus de classe. Editora UNESP, Presidente Prudente, 2006.

ALMEIDA, Rosemeire Aparecida de. (Org.). A questão agrária em Mato Grosso do Sul: uma visão multidisciplinar. Campo Grande: Editora da UFMS, 2008.

ARROYO, Miguel G.. Políticas educacionais e desigualdades: à procura de novos significados. Educ. Soc., Campinas, v. 31, n. 113, p. 1381-1416, dez. 2010. Disponível em <http://www.scielo.br/scielo. php?script=sci_arttext\&pid=S0101-

73302010000400017\&lng=pt\&nrm=iso >. Acesso em: 19 jan. 2016.

BRANDÃO, Carlos Rodrigues. Lutar com a palavra: escritos sobre o trabalho do educador. Rio de Janeiro: Graal, 1982.

BRASIL. Resolução No 466, de 12 de dezembro de 2012. Dispõe sobre dignidade humana e pela especial proteção devida aos participantes das pesquisas científicas envolvendo seres 
humanos. Disponível em: <http://conselho.saude.gov.br/resolucoes/2012/Reso466.pdf $\geq$. Acesso em: 24 ago. 2013.

CASTELLS, M. A Galáxia da Internet: reflexões sobre a internet, os negócios e a sociedade. Rio de Janeiro: Zahar, 2003.

FREIRE, Paulo. A máquina está serviço de quem? Revista Bits. 1884. Disponível em: http://www.paulofreire.org/Crpf/CrpfAcervo000040. Acesso em: 19 set. 2015.

FREITAS, M. T. Letramento digital e formação de professores. Educação em Revista. Belo Horizonte. v.26 | n.03 | p.335-352 | dez. 2010 Disponível em: http://www.scielo.br/pdf/edur/v26n3/v26n3a17.pdf Acesso em: 28 jan 2016

FIALHO, F (org.). Mato Grosso do Sul 2000-2013. São Paulo: Editora Fundação Perseu Abramo, 2014.

GATTI, B. A.; BARRETTO, E. S. S. Professores: aspectos de sua profissionalização, formação e valorização social. Relatório de Pesquisa. Brasília: Unesco, 2009.

GINZBURG, C. O queijo e os vermes: o cotidiano e as idéias de um moleiro perseguido pela Inquisição. São Paulo: Companhia das Letras, 1987.

GOLDENBERG, M. A arte de pesquisar: como fazer pesquisa qualitativa em Ciências Sociais. 2. ed. Rio de Janeiro: Record, 1998.

JUNQUEIRA, Carmem. Antropologia indígena: uma introdução, história dos povos indígenas no Brasil. São Paulo: EDUC, 1999.

KUDLAVICZ, Mieceslau. Dinâmica agrária e a territorialização do complexo celulose/papel na microrregião de Três Lagoas/MS. Dissertação de Mestrado. Programa de Pós Graduação - Mestrado em Geografia/CPTL/UFMS - Área de Concentração Análise Geoambiental e Produção do Território. 177 p.

MARQUES, H. R. et al. Metodologia da Pesquisa e do Trabalho Científico. 4. ed. Campo Grande: UCDB, 2014.

MINAYO, M. C. de S. O desafio do conhecimento: pesquisa qualitativa em saúde. 6. ed. São Paulo: Hucitec, 1999.

MINAYO, M. C. de S. (Org.) Pesquisa social: teoria, método e criatividade. 5. ed. Petrópolis: Vozes, 1996.

MUNARIM, A. Educação do Campo: desafios teóricos e práticos. In: MUNARIM, Antonio et al. (Org.). Educação do Campo: reflexões e perspectivas. Florianópolis, SC: Insular, 2010. p. 9-18.

MUNARIM, I. As tecnologias digitais nas escolas do campo: contextos, desafios e possibilidades. 2014. 184 f. Tese (Doutorado em Educação) - Programa de Pós-Graduação em Educação, Universidade Federal de Santa Catarina, Florianópolis, 2014.

NEGRINE, A. Instrumentos de coleta de informações na pesquisa qualitativa. In: MOLINA NETO, V. M.; TRIVIÑOS, A. N. S. (Org.). A pesquisa qualitativa na Educação Física: alternativas metodológicas. Porto Alegre: Sulina, 1999. p. 61-93. 
NOAL, M. L. Educação do campo: escolas, práticas pedagógicas, tecnologias. In: Anais... III Encontro Nacional de Pesquisa em Educação do Campo: III Seminário sobre Educação Superior e as Políticas para o Desenvolvimento do Campo Brasileiro; I Encontro Internacional de Educação do Campo, 2010, Brasília, DF. Encontro Observatório, 2010.

OLIVEIRA, A. K. L. O.; Santos J. B. F. A influência do trabalho e da práxis na evolução do homem: uma análise a partir de A Guerra do Fogo. In: Anais... XV ENCONTRO DE CIÊNCIAS SOCIAIS DO NORTE E NORDESTE e PRÉ-ALAS BRASIL. Teresina, PI, 2012, p.75-80.

Submetido: $11 / 06 / 2018$

Aprovado: 07/01/2019

Contato:

Miraíra Noal Manfroi

Rua Bráulio de Souza, 258

Campo Grande |MS | Brasil

CEP 79042-030 